\title{
Using the ecosystem services concept to analyse stakeholder involvement in wetland management
}

\author{
Emmanuelle Cohen-Shacham • Tamar Dayan • \\ Rudolf de Groot • Coralie Beltrame • \\ Fanny Guillet $\cdot$ Eran Feitelson
}

Received: 20 April 2013/Accepted: 13 August 2014/Published online: 22 August 2014

(C) Springer Science+Business Media Dordrecht 2014

\begin{abstract}
Wetland management usually involves multiple stakeholders. This paper describes how the use of the ecosystem services (ES) concept can help to identify the main stakeholders associated with wetland conservation, using the Hula Wetland in the Sea of Galilee's watershed as a case study. We conducted a stakeholder analysis based on semi-structured interviews. We focused on the management of two seminatural areas within the larger Hula Wetland area (Hula Nature Reserve and Agamon), in which different management regimes are used and which provide different bundles of ES to different stakeholders. Using the ES concept in the stakeholder analysis, we were able to present the Hula Wetland management in a comprehensive manner. The approach also revealed a lack of coordination between the managing organisations which might lead to competition favouring cultural services (in particular tourism) at the expense
\end{abstract}

E. Cohen Shacham $(\bowtie) \cdot$ T. Dayan

Department of Zoology, Tel Aviv University, 69978 Tel Aviv, Israel

e mail: minacs@gmail.com

E. Cohen Shacham

SIAM Department, Swiss Federal Institute of Aquatic Science and Technology (Eawag), P.O. Box 611, 8600 Dübendorf, Switzerland

\section{R. de Groot}

Environmental Systems Analysis Group, Wageningen University, PO Box 47, 6700 AA Wageningen, The

Netherlands of habitat services (i.e. biodiversity conservation) in the future. To test our method we also conducted a stakeholder analysis in the Camargue Wetland in France. The two wetlands have similar characteristics but are embedded in different institutional contexts. The Camargue Regional Park has a multi-stakeholder platform which could serve as an example for the Hula Wetland to improve its management and lead to better coordination and complementarity of ES provided by the two sub-sites. Our study showed that applying the ES concept helps to quickly identify relevant stakeholders and analyse wetland management in a more holistic way and to point towards sustainable solutions for conflicting stakeholder interests.

Keywords Ecosystem management · Ecosystem services · Hula Wetland · Stakeholder analysis

\author{
C. Beltrame \\ Department of Monitoring, Evaluation and Wetland \\ Policy, La Tour du Valat, Le Sambuc, 13200 Arles, \\ France \\ F. Guillet \\ CERSP UMR 7204, Muséum National d'Histoire \\ Naturelle, 55 rue Buffon, 75005 Paris, France \\ E. Feitelson \\ Department of Geography, The Hebrew University of \\ Jerusalem, Mount Scopus, 91905 Jerusalem, Israel
}




\section{Introduction}

Sustainable wetland management is hampered by a lack of coherent and holistic approaches. The analysis of ecosystem services (ES), defined as the benefits that people derive from ecosystems (MA (Millennium Ecosystem Assessment) 2005), may offer such a comprehensive framework for decision-making in wetland management. ES include four main categories: provisioning, regulating, cultural, and supporting/habitat services (MA (Millennium Ecosystem Assessment) 2005; de Groot et al. 2010; TEEB 2010). Much research has been carried out on ES frameworks, classification and valuation (de Groot et al. 2002; Costanza et al. 1997; Daily and Ellison 2002; TEEB 2010). Nevertheless, a major challenge remains: how to apply the ES concept in actual management and decision-making processes (Kremen 2005; Maynard et al. 2010; de Groot et al. 2010), whereby stakeholder involvement is essential to assess the relative value of different management options (Seppelt et al. 2011).

We studied how the use of the ES concept may contribute to wetland conservation by applying it to ecosystem management. Two main approaches have been developed for ecosystem management regimes: preservation and conservation. Conservation management refers to the sustainable use and careful management of natural resources; it involves preventing loss or damage to ecosystems, but allows human intervention where necessary (Barnett and Morse 1963). This approach is similar to the "wise use of the wetlands" as promoted by the Ramsar Convention (Ramsar Convention Secretariat 2010). Preservation management refers to the protection of the environment, while ensuring minimal impact by humans (Leopold 1949; Nash 1989). These different management regimes are applied to natural resources, depending on the mission and ethics of the organisations in charge of particular areas (Avni 2003).

Here we analyse the management regime of the Hula Wetland, using the ES concept. We performed a stakeholder analysis based on semi-structured interviews. We analysed stakeholder involvement in the wetland management and how their different mission statements are implemented. Based on this information, we provide a review of the available management tools and mechanisms in place in the wetland and analyse the interrelationships between the stakeholders. We focus on the semi-natural areas in the wetland, which are managed differently and provide different types of ES. Finally we test this method in the Camargue Wetland in France, which we compare to the outcome of the Hula study its management system.

Study site

The Hula Valley was originally a 6,000 ha wetland, a large freshwater lake with upstream swamps. It is located in the north of the Jordan Valley in the watershed basin of the Sea of Galilee ${ }^{1}$ (Committee on Sustainable Water Supplies for the Middle East 1999), Israel's major surface water reservoir and the source of water supply for the national system, local consumers and the Kingdom of Jordan, providing between a quarter and a third of the country's natural water supply (Tal 2006). The upper Jordan River contributes 440 million cubic meters of water per year to the Sea of Galilee (average for the period 1975 2008), while the rest comes from precipitation, streams flowing from the Golan Heights and springs (Klein 1998).

This unique ecosystem was drained in the 1950s, in an attempt to increase the water potential for the country and to convert the swamps into arable land (Avnimelech et al. 1978; Hambright and Zohary 1998). This was done despite concerns expressed by experts on the possible outcome of such a project (Avnimelech 1999). In parallel to the drainage and due to pressure from scientists and nature conservationists, an area of 430 ha was designated to create a nature reserve. The area was reduced to 320 ha in 1959 (Paz1975). In 1964, the Hula Nature Reserve was finally created becoming Israel's first nature reserve (Dimentman et al. 1992; Duany 2010), then managed by Israel Nature Reserves Authority (currently the Nature and Parks Authority).

Over the following decades, severe problems developed: the groundwater table level decreased and air penetrated into the dry peat, enhancing microbial decomposition of organic matter and leading to underground fires (Avnimelech et al. 1978). The peat soil at the centre of the Hula Valley subsided up to three meters (Shaham et al. 1990), its decomposition led to the release of large amounts of nutrients washed into the Jordan River, eventually leading to eutrophication in the Sea of Galilee (Avnimelech 1999). A watershed authority, the Kinneret Lake Authority, was established

\footnotetext{
${ }^{1}$ Lake Kinneret is the Israeli name for Sea of Galilee, also known as Lake Tiberias.
} 
in 1969 by the government to prevent water pollution and to address water quality problems in the Sea of Galilee. In addition, the Hula committee was established, with the mandate to coordinate the activities in the Hula Valley (Avnimelech 1999).

During the degradation phase that followed the drainage process, the Hula Nature Reserve helped conserve part of the original landscape, but it could not prevent the extinction of animals and freshwater plant species, some of which were endemic (Paz 1975; Furth 1976). The subsiding peat soil in the drained area left the nature reserve at a much higher elevation and isolated from the rest of the Valley. A feasibility study was initiated by the Hula Committee together with the Kinneret Authority that included three alternative plans to rehabilitate the area (Shaham et al. 1990). This led to a major rehabilitation project, to restore the peat soil, promote tourism and protect the Sea of Galilee from increasing nutrient loads (Gutman et al. 2001;Markel 2004; Shaham et al. 1990). As part of this project, 100 ha of the new cropland were re-flooded to create the Agamon Lake, as well as a network of $90 \mathrm{~km}$ of shallow flood and drainage canals (Hambright and Zohary 1998). The Jordan River's historic route, which passes through the center of the valley, was rehabilitated to form the Lake's primary water source (Hambright and Zohary 1998; Markel et al. 1998), bringing relatively high-quality water mainly in summer. The lake's second water source comes from a drainage canal that brings poorer-quality peat drainage waters (Markel et al. 1998). Several practical actions were taken to minimise potential nutrient flow to the Sea of Galilee: (1) diversion of water outflows from the Agamon to the Einan reservoir (Markel et al. 1998); (2) vertical placement of a plastic sheet from soil surface level to 4.5 meter deep across the valley, south to Agamon Lake, to reduce underground water infiltration (Gophen et al. 2003); and (3) construction of a pipeline to carry sewage effluents to a treatment reservoir; all waters in the reservoir would be treated and reused in agriculture (Hambright and Zohary 1998). The Agamon project helped rehabilitate the diverse wetland ecology including an important resting habitat for migrating birds en route between Africa and Europe (Shy et al. 1998; Shmueli et al. 2000; Olsvig-Whittaker et al. 2005; Labinger and Skutelsky 2005). The rehabilitation opened new bird-watching and tourism opportunities (CohenShacham et al. 2011), which were developed in the Agamon Site. Touristic activities are very developed, with many trails for tourists and modes of transport within the Agamon site: bicycles, clubcars, camouflaged tractor-drawn trailers and a shuttle bus (CollinsKreiner and Israeli 2010), Today the historical Hula Wetland area is a mosaic of (semi) natural, agricultural and water land cover and land use types, which partially provides ES in all four categories provisioning, regulating, cultural and habitat services as a result of the complex management system (see Fig. 1). In this paper, the "Hula Wetland" refers to the Hula's pre-drainage historical wetland area, including the lake, the swamps and the areas flooded during part of the year ("study area" in Fig. 1).

Two main agencies manage the two semi-natural sites in the Hula Valley: the Nature and Parks Authority (NPA), which manages the Hula Nature Reserve and the Jewish National Fund Keren Kayemeth LeIsrael (JNF-KKL), which coordinates the management and maintenance of the Agamon site (Labinger and Skutelsky 2005).

The NPA was originally composed of two organisations which separately managed nature reserves and national parks. These have officially merged in 1998, to form the Israel Nature and National Parks Protection Authority, the so-called Nature and Parks Authority. The NPA constitutes the framework for enforcement and conservation, dedicated to developing, protecting and promoting inter alia Israel's natural sites that are in the process of formally becoming national parks and nature reserves (Tal 2006). Since its fusion, the NPA manages the protected areas according to both preservation and conservation management regimes, depending on the protected area's designation (nature reserve or national park) (Avni 2003).

The JNF-KKL was established in 1901 and is one of Israel's primary national institutions, originally founded to buy and develop the land for Jewish settlement. Since the 1960s the organisation has led or sponsored various environmental projects, in specific action areas such as water, environment, tourism and recreation. According to JNF-KKL's policy principles, as promulgated in the last decade, it acts to conserve and improve the capacity of nature and its ability to provide ES, by preventing damage through destructive exploitation (Amir and Rechtman 2006). Although the JNF-KKL is responsible for the management, development and preservation of the Agamon site, the latter is legally owned and managed according to an official agreement between the Israel Lands Administration and the representatives 
Fig. 1 Map of the semi natural areas in the Hula Wetland (Cohen Shacham et al. 2011). The dashed "study area" refers to the Hula's pre drainage historical wetland area, including the lake, the swamps and the areas flooded during part of the year ("Hula Wetland" as referred to in this paper)

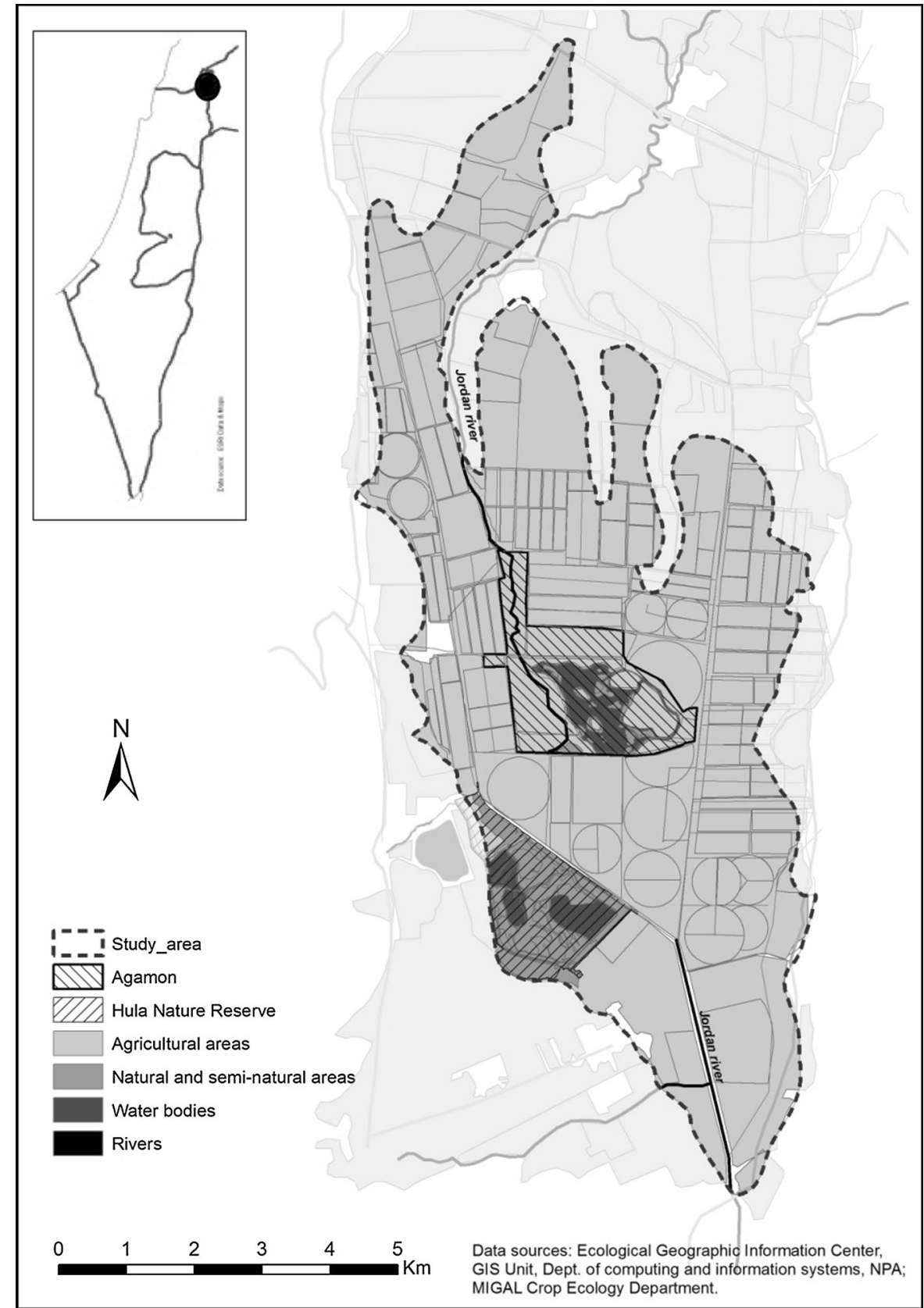

of 18 local villages, known as "Nahlat Hamoshavim Cooperative" (Labinger and Skutelsky 2005).

\section{Methods}

A four-step stakeholder analysis was performed to analyse the Hula Wetland management, portrayed schematically in Fig. 2.
Stakeholder selection (Step 1)

In spite of the existing debate regarding the relative usefulness of data-gathering through interviews (Cast et al. 2008), some qualitative information cannot be gathered in any other way (Armstrong et al. 1997; Thompson 2000). The subjective perspective gained during the interviews proved very important here to better understand the factors and 


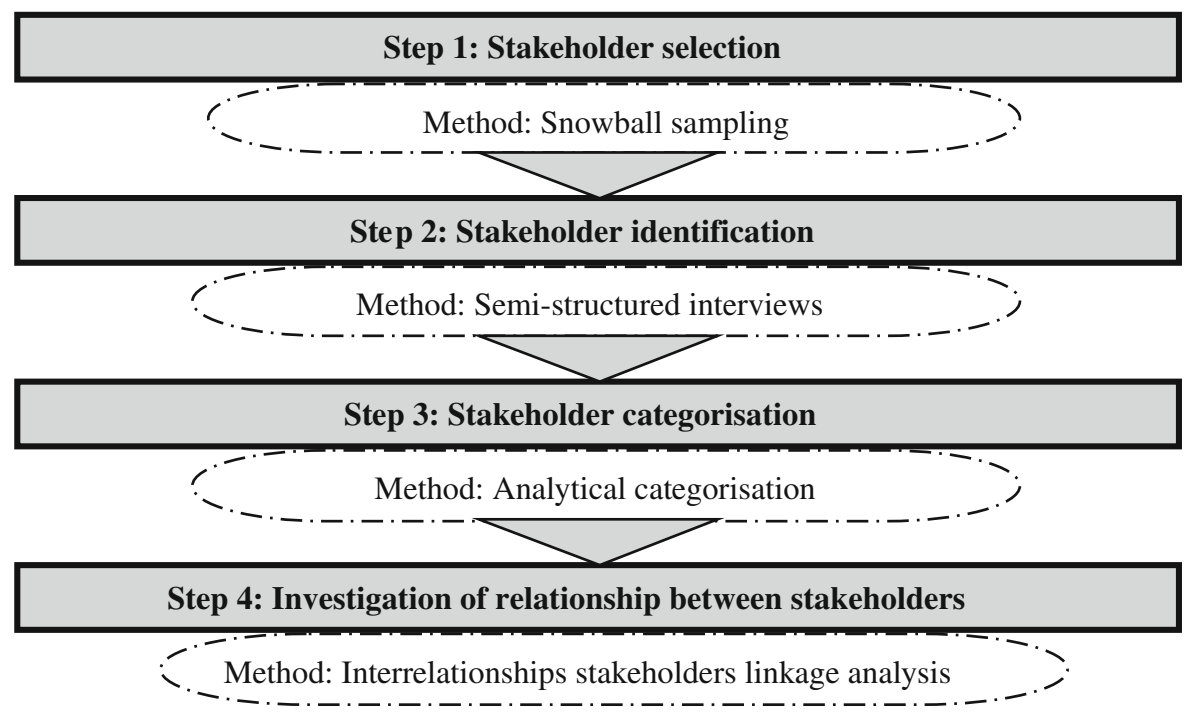

Fig. 2 Steps of Hula Wetland stakeholder analysis (adapted from Grimble and Wellard 1997; Grimble 1998; Reed et al. 2009)

considerations underlying the management of the Hula Wetland. We first mapped the stakeholders and decision makers involved in the management of natural resources at the Hula Wetland. The selection was based on three sources: our own acquaintance with some of the stakeholders and decision makers, upon which a preliminary list was prepared; literature review; and a "snowball" sampling method, which involves asking the interviewees themselves to refer to other relevant stakeholders and decision makers that should be included in the list of interviewees (Patton 1990; Trop 2001; Scolozzi et al. 2012).

\section{Stakeholder identification (Step 2)}

Semi-structured interviews were conducted by the first author from July 2009 to December 2010. They were based on a previously prepared questionnaire, consisting of open-ended questions. The questionnaire started with general questions to let the interviewees answer freely and then slowly moved toward more focused questions to get the interviewees opinion on specific points. Stakeholders and decision makers were first asked about their roles in the decisionmaking process and how much they had been involved in it; what they would have changed in the past or at present time if they could have done so; how did the decision-making process take place; what the management goals and principles were, in the organisation they are/were working for; what management tools were used; whether they were aware of the principles/ guidelines of the Ramsar Convention on Wetlands and if so, whether these were taken into account and implemented in the management or decision-making processes. The interviewees were then asked what was important to preserve in the framework of the management process and why, while they were led to develop their ideas and to understand what ES they actually referred to, even if they were not explicitly referred to as such. For instance, they were asked questions such as "Why is it important and beneficial to keep this species? Why is it better to limit the number of visitors? Why is it important to keep the water quality good?" Next, if these objectives were achieved, they were asked how they could verify that the results fitted their expectations and if and to what extent they had used ecological data in the decisionmaking process. The interviews ended by asking if the objectives of, and cooperation with the other organisations were taken into account in the management process. During the interviews, there were occasionally slight changes in the interview structure, depending on the interviewee's background and profession. The interviews lasted between $30 \mathrm{~min}$ to $4 \mathrm{~h}$ and they were all tape recorded.

A total of 70 stakeholders relevant to natural resource management at the Hula Wetland were selected and interviewed. The selected interviewees ranged from low to high levels in decision-making processes and belonged to: governmental and semi- 
governmental agencies; a non-governmental organisation (NGO); research centres and universities; the private sector; and stakeholders in the local community involved in the Hula management process (see list of stakeholder categories in Table 1). Some of the

Table 1 Stakeholders interviewed during this research project

\begin{tabular}{|c|c|}
\hline Stakeholder category & $\begin{array}{l}\text { Agencies involved (number } \\
\text { of interviewees) }\end{array}$ \\
\hline $\begin{array}{l}\text { Governmental organisation } \\
\text { (national level) }\end{array}$ & $\begin{array}{l}\text { Ministry of Environmental } \\
\text { Protection (2) } \\
\text { Ministry of Agriculture (2) } \\
\text { Water Authority (1) } \\
\text { Nature and Parks Authority } \\
\text { (14) }\end{array}$ \\
\hline $\begin{array}{l}\text { Governmental organisation } \\
\text { (regional level) }\end{array}$ & $\begin{array}{l}\text { Kinneret Authority (1) } \\
\text { Upper Galilee Regional } \\
\text { Council (2) } \\
\text { Merom Galil regional } \\
\text { council (1) } \\
\text { Mevoot Hermon regional } \\
\text { council (1) }\end{array}$ \\
\hline $\begin{array}{l}\text { Semi governmental } \\
\text { organisation }\end{array}$ & JNF KKL (5) \\
\hline NGO & $\begin{array}{l}\text { Society for the protection of } \\
\text { nature in Israel (6) }\end{array}$ \\
\hline $\begin{array}{l}\text { Local and national universities } \\
\text { and research centres }\end{array}$ & $\begin{array}{l}\text { University of Haifa (5) } \\
\text { Hebrew University of } \\
\text { Jerusalem (4) } \\
\text { Kinneret Limnological } \\
\text { Laboratory (3) } \\
\text { Migal Galilee Research } \\
\text { Institute (4) } \\
\text { Technion (1) } \\
\text { Tel Aviv University (3) } \\
\text { Tel Hai College (1) } \\
\text { Volcani Center (1) } \\
\text { Research Institute outside } \\
\text { Israel (1) }\end{array}$ \\
\hline Private sector & $\begin{array}{l}\text { Tahal group Engineering } \\
\text { company (1) } \\
\text { Private planner (1) } \\
\text { Agamon tourism operating } \\
\text { organisation (4) }\end{array}$ \\
\hline Agricultural cooperative & $\begin{array}{l}\text { Upper Galilee's water } \\
\text { factories (1) } \\
\text { Farmers (including Nahlat } \\
\text { Hamoshavim) (3) }\end{array}$ \\
\hline Local community & $\begin{array}{l}\text { Kibbutz Amir (1) } \\
\text { Kibbutz Hulata (1) }\end{array}$ \\
\hline
\end{tabular}

interviewed stakeholders provided information that was useful and complementary to understanding of the general framework of the wetland management, but were not listed in the results section due to their minor role in the stakeholders' analysis as an independent group.

The data gathered during the interviews was completed by collecting and reviewing documents related to the studied wetland. The information was found in archives documenting management stages, and grey literature such as management plans and committee meeting protocols. These documents were available in the on-site Hula Nature Reserve library or directly from the interviewees.

\section{Stakeholder categorisation (Step 3)}

We first made two major distinctions between the stakeholder categories following Grimble and Wellard's (1997) classification:

1. Key stakeholders (considered to have a significant influence on the success of an ecosystem management project), active stakeholders (who affect or determine a decision or action in the project), or passive stakeholders (affected, positively or negatively, by decisions or actions of others).

2. Primary (mostly affected by the outcome of the project, either in a positive "beneficiaries" or negative way), or secondary stakeholders ("intermediary" stakeholders within a project) who are not directly affected by the outcome of the project, but have an interest in it, e.g., government agencies, funding institutions, monitoring agencies, or governmental, NGO and private sector key individuals.

Each stakeholder group was defined according to these categories and their involvement in the Hula Wetland was presented, including the tools they use for management. These include the committees that they are involved in and within which they interact and many of the management decisions pertaining to the Hula Wetland are made:

1. The Hula Maintenance Committee (HMC), which is headed by the Kinneret Drainage Authority (statutorily the authority in charge of the peat soil through KKL) and the Kinneret Authority. It is responsible for the maintenance and operation of 
the Hula rehabilitation project (e.g. control of the water level in the peat soil) (www.kineret.org.il/).

2. The Hula Valley Public Committee (HVPC), whose chairperson is directly appointed by the Ministry of Interior. According to the Hula Master Plan, this statutory committee is appointed for sustainable development of landscape and recreation in the Hula Valley. It is responsible for directing the scientific research within the Hula Project area (Labinger and Skutelsky 2005) and focuses on issues such as the development, tourism and land uses in the Hula Valley.

3. The Cranes Team (CT) is headed by the Upper Galilee Crops Committee. It is responsible for preventing damage to the agricultural areas in the Hula Valley. This is done by population counts, protecting the fields that were just seeded and by opening crane feeding stations to concentrate them in particular areas.

4. Large Tourism Authority (LTA) is headed by the Ministry of Agriculture and Rural Development. It is responsible for everything linked to tourism in the Hula Project area, and includes a total of 25 different organisations.

5. Small Tourism Management body (STM) is headed by JNF-KKL. It is responsible for the ongoing management of the Agamon touristic site.

6. Hula Nature Reserve Management Forum (NRMF) is headed by the NPA. It is responsible for the ongoing ecological management of the Hula Nature Reserve.

7. Trout Committee (TC). It operates a monitoring system to determine phosphorus loads emitted from trout farms to the Sea of Galilee's catchment, it guides fishermen on how to prevent pollution and determines the maximum allowable emission thresholds (http://www.water.gov.il/).

Investigation of relationships

between stakeholders (Step 4)

Finally we investigated the relationship between different stakeholders based on the interviews, stakeholders' matrix and literature review. In complex situations, where there is a large number of stakeholders with very different interests regarding the resource, matrices can be a useful analytical tool for identifying and assessing the significance of conflicts of interest and cooperation between different stakeholder groups (Grimble et al. 1995). We therefore prepared an interrelation stakeholder linkage matrix, which lists the relevant stakeholders and describes the interrelationships between them. Different codes were used to show the existing conflicts of interest, the existing work complementarities and whether cooperative actions were taken.

\section{Results}

\section{Stakeholder matrix}

In addition to the NPA and JNF-KKL presented earlier, several stakeholders are present directly onsite, or are involved indirectly in the management of the site. The stakeholder matrix in Table 2 synthesises the management information gathered during semi-structured interviews and from the literature review.

In addition, some programs were prepared by various stakeholders to address the different issues in the Hula Wetland and are implemented in part:

1. The Master Plan for Sustainable Development of Landscape and Recreation in the Hula Valley, initiated by JNF-KKL, was prepared in 2002. It aims at helping to resolve the conflict between agriculture, ecology and tourism, and to generate new synergies between them. This Master Plan emphasises the need to preserve the agricultural character of the Hula Valley, its natural and environmental values in general, and its bird fauna in particular.

2. In 2009, the Upper Galilee Regional Council prepared a "Comprehensive Spatial Plan in a Sustainable Development Vision" to coordinate and map all the existing sustainable development related programs, operations and processes that existed for the area. This has been done in order to outline the policies and tools and further implement the existing concepts and promote environmental issues in the area in the future.

3. The Life Program for the Sustainable Development of the Jordan River sources was prepared in 2009. It focuses on the Northern Jordan Valley down to the Sea of Galilee, is implemented at 
Table 2 Stakeholder matrix of the Hula Wetland management. "Primary stakeholders": affected by the outcome of the project, either in a positive or negative way; "secondary stakeholders": indirectly affected by the outcome of the project

\begin{tabular}{|c|c|c|c|}
\hline $\begin{array}{l}\text { Stakeholder group } \\
\text { name }\end{array}$ & Stakeholder definition & $\begin{array}{l}\text { Stakeholder's involvement in Hula } \\
\text { Wetland management }\end{array}$ & $\begin{array}{l}\text { Tools used for ecosystem } \\
\text { management }{ }^{\mathrm{a}}\end{array}$ \\
\hline \multicolumn{4}{|l|}{ Key stakeholders } \\
\hline $\begin{array}{l}\text { Nature and parks } \\
\text { authority (NPA) } \\
\text { (Secondary) }\end{array}$ & $\begin{array}{l}\text { Government affiliated agency } \\
\text { (under the Ministry of } \\
\text { Environmental Protection), } \\
\text { managing nature reserves and } \\
\text { national parks in Israel }\end{array}$ & $\begin{array}{l}\text { Responsible for the Hula Nature } \\
\text { Reserve management (plan and } \\
\text { implementation) } \\
\text { Main interest is to preserve nature }\end{array}$ & $\begin{array}{l}\text { Rehabilitation Plan (1975); } \\
\text { Management Plans (2008); } \\
\text { annual reports; Regular } \\
\text { monitoring; Maintenance; Part } \\
\text { of: HMC; HVPC; CT; LTA; } \\
\text { NRMF; TC }\end{array}$ \\
\hline $\begin{array}{l}\text { Jewish National } \\
\text { Fund Keren } \\
\text { Kayemeth } \\
\text { LeIsrael (JNF } \\
\text { KKL) } \\
\text { (Secondary) }\end{array}$ & $\begin{array}{l}\text { Semi governmental non profit } \\
\text { organisation that was a founding } \\
\text { national institution }\end{array}$ & $\begin{array}{l}\text { Responsible for the Agamon site } \\
\text { management (statutorily as } \\
\text { contractor under the Kinneret } \\
\text { drainage authority). Its main goal } \\
\text { is to promote tourism at the } \\
\text { Agamon site, while keeping a } \\
\text { good quality of the water flowing } \\
\text { to the Sea of Galilee, managing } \\
\text { the Agamon site and preventing } \\
\text { damage to the agricultural area }\end{array}$ & $\begin{array}{l}\text { Regular meetings; Working plan } \\
\text { updated twice a year; Monitoring } \\
\text { used for changing management if } \\
\text { needed; Adaptive management } \\
\text { based on research; Maintenance; } \\
\text { Part of: HMC; HVPC; CT; LTA; } \\
\text { STM }\end{array}$ \\
\hline \multicolumn{4}{|l|}{ Active stakeholders } \\
\hline $\begin{array}{l}\text { Society of } \\
\text { protection of } \\
\text { nature in Israel } \\
\text { (SPNI) } \\
\text { (Secondary) }\end{array}$ & $\begin{array}{l}\text { Largest nature conservation NGO } \\
\text { in Israel }\end{array}$ & $\begin{array}{l}\text { Managing the birds' center, } \\
\text { located in the Agamon site. } \\
\text { Promote birdwatching and } \\
\text { educational activities in the Hula } \\
\text { Valley. Participate in monitoring } \\
\text { for the JNF KKL and the Water } \\
\text { Authority }\end{array}$ & Part of: HMC; HVPC; CT; LTA \\
\hline $\begin{array}{l}\text { Water authority } \\
\text { (Secondary) }\end{array}$ & $\begin{array}{l}\text { Governmental water authority, } \\
\text { responsible for water and sewage } \\
\text { treatments and policies. } \\
\text { Treatment plans located } \\
\text { downstream Hula Valley }\end{array}$ & $\begin{array}{l}\text { Coordinates and responsible for } \\
\text { the water quality data in the Hula } \\
\text { Valley and downstream to the } \\
\text { Sea of Galilee (with the data } \\
\text { with the Kinneret Laboratory and } \\
\text { the Kinneret Authority) }\end{array}$ & $\begin{array}{l}\text { Monitoring of water related data. } \\
\text { Part of: HMC; HVPC; LTA; } \\
\text { NRMF; TC }\end{array}$ \\
\hline $\begin{array}{l}\text { Kinneret authority } \\
\text { (Primary) }\end{array}$ & $\begin{array}{l}\text { Governmental. Financed by the } \\
\text { Water Authority. It is part of the } \\
\text { Kinneret Drainage and Streams } \\
\text { Authority (statutory and non } \\
\text { profit institution whose authority } \\
\text { is mainly depending on the right } \\
\text { of nature for water) and its } \\
\text { professional functions are } \\
\text { coordinated together with it }\end{array}$ & $\begin{array}{l}\text { Main goal: Prevent pollution in the } \\
\text { Sea of Galilee's watershed and } \\
\text { maintain water quality it the Sea } \\
\text { of Galilee. } \\
\text { Initiated the feasibility study that } \\
\text { led to the rehabilitation project. } \\
\text { Prepared the technical } \\
\text { maintenance plan of the Agamon } \\
\text { rehabilitation project, which is } \\
\text { implemented }\end{array}$ & $\begin{array}{l}\text { Working with Kinneret Laboratory } \\
\text { for monitoring; Part of: HMC; } \\
\text { HVPC; TC }\end{array}$ \\
\hline $\begin{array}{l}\text { Ministry of } \\
\text { agriculture and } \\
\text { rural } \\
\text { development } \\
\text { (Secondary) }\end{array}$ & $\begin{array}{l}\text { Governmental body responsible } \\
\text { for agriculture and rural space }\end{array}$ & $\begin{array}{l}\text { Involved in Hula management } \\
\text { mainly through participation in } \\
\text { committees }\end{array}$ & Part of: HVPC; LTA \\
\hline $\begin{array}{l}\text { Ministry of } \\
\text { environmental } \\
\text { protection } \\
\text { (Secondary) }\end{array}$ & $\begin{array}{l}\text { Governmental body established in } \\
\text { 1988. It establishes national } \\
\text { policies, develops strategies and } \\
\text { standards, and sets priorities to } \\
\text { protect the environment }\end{array}$ & $\begin{array}{l}\text { Involved in Hula management } \\
\text { through participation in } \\
\text { committees and its } \\
\text { representatives at the NPA }\end{array}$ & Part of: HVPC; TC \\
\hline
\end{tabular}


Table 2 continued

\begin{tabular}{|c|c|c|c|}
\hline $\begin{array}{l}\text { Stakeholder group } \\
\text { name }\end{array}$ & Stakeholder definition & $\begin{array}{l}\text { Stakeholder's involvement in Hula Wetland } \\
\text { management }\end{array}$ & $\begin{array}{l}\text { Tools used for ecosystem } \\
\text { management }\end{array}$ \\
\hline $\begin{array}{l}\text { Mekorot } \\
\quad \text { (Secondary) }\end{array}$ & $\begin{array}{l}\text { Israel National Water } \\
\text { Company (Feitelson } \\
\text { et al. 2007). Mekorot } \\
\text { is owned by the State } \\
\text { of Israel } \\
\text { and is responsible for } \\
\text { the water distribution } \\
\text { in the country }\end{array}$ & $\begin{array}{l}\text { Responsible for the Einan reservoir and the } \\
\text { treatment reservoir, which collect, treat the } \\
\text { peat water from the Agamon and water from } \\
\text { the western underground channel, and } \\
\text { transfer it for irrigation. It owns the pumping } \\
\text { station that delivers the Jordan River water, } \\
\text { pumped in the Western Channel, to the } \\
\text { Nature Reserve (Skutelsky and Oron 2008) }\end{array}$ & $\begin{array}{l}\text { Mekorot is part of the } \\
\text { maintenance committee of the } \\
\text { Agamon }\end{array}$ \\
\hline \multicolumn{4}{|l|}{ Passive stakeholders } \\
\hline $\begin{array}{l}\text { Regional } \\
\text { councils } \\
\text { (Secondary) }\end{array}$ & $\begin{array}{l}\text { Regional governmental } \\
\text { offices upstream and } \\
\text { around the Hula Valley }\end{array}$ & $\begin{array}{l}\text { Not directly taking part in wetland } \\
\text { management. The agricultural company } \\
\text { (financial and professional body in the upper } \\
\text { Galilee Regional Council) participates in } \\
\text { research, is partner in the cranes project and } \\
\text { in the management of agricultural areas }\end{array}$ & $\begin{array}{l}\text { Part of: HVPC; LTA; STM, TC. } \\
\text { Relatively passive partner in the } \\
\text { "Nahlat Hamoshavim } \\
\text { Cooperative" }\end{array}$ \\
\hline $\begin{array}{l}\text { Agamon tourism } \\
\text { operating } \\
\text { organisation } \\
\text { (Primary) }\end{array}$ & $\begin{array}{l}\text { Private company, } \\
\text { operating all } \\
\text { tourist activities in the } \\
\text { Agamon site }\end{array}$ & $\begin{array}{l}\text { Interested in developing tourism for larger } \\
\text { income. } \\
\text { Its management is set and decided by the Small } \\
\text { Tourism Management body (headed by KKL) }\end{array}$ & Part of: CT; LTA; STM \\
\hline $\begin{array}{r}\text { Researchers } \\
\text { (Primary) }\end{array}$ & $\begin{array}{l}\text { Research institutes or } \\
\text { universities } \\
\text { who carry out part of } \\
\text { their } \\
\text { research at the Hula }\end{array}$ & $\begin{array}{l}\text { Not directly involved in wetland management } \\
\text { plan, but take part in the Hula monitoring and } \\
\text { interested in wetland's functioning and values } \\
\text { (Barnea 2011) }\end{array}$ & $\begin{array}{l}\text { Part of: HVPC; NRMF } \\
\text { (amphibians, fish and } \\
\text { invertebrates' experts) }\end{array}$ \\
\hline $\begin{array}{l}\text { Farmers and } \\
\text { "Nachalat } \\
\text { Hamoshavim" } \\
\text { (Primary) }\end{array}$ & $\begin{array}{l}\text { Land owners, part of } \\
\text { farmers' corporation }\end{array}$ & $\begin{array}{l}\text { Interested in having productive crops and } \\
\text { higher income. Dependent on a good state of } \\
\text { the peat soil. Finance about a third of the fees } \\
\text { for the Cranes project. Influence the } \\
\text { management of the Agamon site }\end{array}$ & $\begin{array}{l}\text { Part of: HMC; HVPC; CT; LTA; } \\
\text { STM }\end{array}$ \\
\hline
\end{tabular}

${ }^{a}$ Management tools include the committees attended by stakeholders: $H M C$ The Hula Maintenance Committee, HVPC The Hula Valley Public Committee, CT Cranes team, LTA Large Tourism Authority; STA Small Tourism Management body, NRMF Hula Nature Reserve Management Forum, TC Trout Committee

different levels and was the result of an initiative from the Jordan Sources Stream Administration in the area. This project involved the Ministry of Environmental Protection, the Ministry of Agriculture, the regional Councils, JNF-KKL, NPA, The Kinneret Drainage Authority and the SPNI (Jordan Sources Stream Administration 2009).

4. A second phase of the Agamon Restoration Project is currently in place, to increase the agricultural restored peat areas and tourist area in the Agamon site.

Ramsar has produced a substantial range of guidelines and insight on how wetlands can be integrated in water management processes for the benefit of all elements of society (Ramsar COP9 2005; Ramsar COP10 2008). One of the questions that the stakeholders were asked was whether they knew the principles and guidelines of the Ramsar Convention on Wetlands, if these are taken into account and implemented in the management or decision-making processes. In spite of the importance of the Ramsar principles and guidelines used for wetland management, most interviewed stakeholders stated that they didn't know the Ramsar guidelines on wetland management. Nevertheless, the Nature Reserve's designation status itself, as a Ramsar site (in 1996) was recognised as important and helpful politically, for the site's conservation. 
Finally, when the interviewees were asked to develop their ideas regarding the provided ES they had referred to in one or two of the natural areas (Agamon and the Hula Nature Reserve), the general answer was that both areas provide similar types of ES. The practical actions that were taken to minimise potential nutrient flow to the Sea of Galilee have replaced the major regulating services in the Hula Wetland. Cultural services are provided in both natural sites, but at a much higher level in the Agamon Site due to the easy access of nearly the entire site to the public, and the variety of activities offered to tourists. Habitat services are also provided at both sites, but to a much greater extent in the Hula Nature Reserve, due to the large closed area. Provisioning services were referred to as being mainly provided by the agricultural areas surrounding both natural areas. Finally, the interviewees referred to a current rather balanced situation of cultural and habitat services between both sites.

\section{Analysis of stakeholder interrelationships}

The diversity of the Hula Wetland management tools and programs and the number of interacting stakeholders involved lead to both collaboration and to conflicts of interest, as described for the following stakeholders below:

1. Interactions between SPNI and Agamon/JNFKKL: JNF-KKL provides the budgets for monitoring and research, which involves the SPNI (and in some cases additional researchers) who wish to influence the Agamon site management toward a more nature conservation oriented track. However, their results and recommendations are often not implemented. For instance, different studies on visitor carrying capacities were carried out by SPNI but not implemented. The Agamon site's carrying capacity is currently assessed by the availability of parking space and not based on the study that KKL commissioned.

2. Interactions between the farmers and JNF-KKL: During the crane migration period, every day thousands of birds stop to rest in the Hula Wetland, en route from Europe to Africa and back. The Crane project was established to keep the birds away from the newly seeded areas by opening feeding stations to lure the cranes. According to a JNF-KKL representative, feeding stations are used here as a management tool and its goal is not to attract more cranes for tourism purposes, although the farmers perceive that differently. The cost of this project (which includes the large amount of food used to attract the cranes and the people in charge of moving the cranes from the fields to the designated areas) is shared between JNF-KKL, the farmers and Agamon. The farmers feel that JNF-KKL and Agamon only want to promote tourism and want them to pay all the project's costs.

3. Interactions between SPNI and farmers: SPNI recommends keeping the water level relatively low in the newly rehabilitated Agamon Lake, so that the cranes can stand and remain protected at night. The farmers, however, want the water level to be higher to keep the peat soil wet and better able to maintain their crops, thus there is a conflict. In this case, the maintenance committee helps moderate between the different organisations, since all stakeholders have to discuss and reach an agreement on the different issues.

4. Interactions between NPA and JNF-KKL: the two agencies cooperate on ecological issues and exchange information for the monitoring that is performed in the Valley. Regarding tourism and public entrance, there is no cooperation. The Agamon offers the public more space and tourism facilities than the nature reserve. Since the latter is located south to the Agamon site, which is on the way to the Agamon area for many tourists, these sites are often confused and many people enter the reserve first, before getting to the Agamon site. The nature reserve and Agamon Site are managed independently by the NPA and the JNF, respectively, each with its own approach towards ecosystem management. The Agamon site is operated by a private tourist company whereas the NPA is a government-agency. During the interviews, both NPA and JNF-KKL claimed a willingness to cooperate with each other, but no common mechanism or no real cooperation occurs, even at the local level. Some ideas were raised, such as a common ticket that could give an entrance to both sites and which would support both sites, and a trail linking the two sites, but nothing materialised.

5. Interactions between Mekorot and NPA: until 2004, Mekorot, Israel's National Water Company, 
and the NPA were in conflict because Mekorot kept the water of high quality for human consumption, and directed water of very low quality (from fish ponds, rich with nutrients) to the nature reserve. Only in 2004 this stopped with the modification of the Water Law to incorporate "the Right of Nature for Water". Until then water was retained for nature only through ad hoc agreements between the Water Commissioner and the NPA. Since then, nature is a 'legitimate' water user, to which water can be allocated under the Water Law (Feitelson and Rosenthal 2012).

In Table 3, we present an interrelation stakeholder linkage matrix, based on the information given above

Finally, one more point that was obvious from the interviews was the scale-dependent level of cooperation. Local stakeholders view it as rather good at the local level but nonexistent at higher levels. This can lead to conflicts between different stakeholders and within a stakeholder group. For instance, at the NPA, interviewees often referred to the pressure from the higher levels of the organisation to open the closed area of the Hula Nature Reserve and allow tourists to enter there as well (in addition to the small designated open area), in order to compete with the Agamon and generate higher income from cultural services provided to tourists. An example for a large and costly initiative resulting from the pressure from higher levels of the NPA is the construction of an interactive cinema in the Hula Nature Reserve, to increase the income from tourism.

Based on our analysis we identified many tools and programs in place for the management of the Hula Wetland. However, due to the numerous stakeholders involved in the various managed issues, the management system is very complex, leading to both cooperation and conflict. More specifically, with regard to natural resources and semi-natural areas, the stakeholder analysis allows us to observe a lack of coordination and cooperation between the Hula Wetland managing organisations that may lead to problematic issues in the conservation of natural resources and the sustainable management of the entire area.

Although the provision of regulating services seems to be similar and presently complementary between both sites, we observe competition, and a lack of collaboration and coordination in ecosystem management between the two sites. As described earlier, the
NPA wants to promote tourism and to open the closed area of the nature reserve for tourists, due to budget pressures. This may divert the NPA from its preservation management regime to the significant emphasis on tourism. Such competition for cultural services between two sites may come at the expense of losing habitat services that are provided in the nature reserve. The ES concept helps to obtain a fuller picture of all stakeholder interests and diagnose problems and opportunities related to the cooperation between the different bodies involved in natural resources management.

\section{Use of the ecosystem services concept in the Camargue Wetland, France}

Box: description of the Camargue Wetland and its management system

In order to provide better insight into the results of our study, we compared the Hula Wetland management system to the Camargue Wetland in southern France. Here too we focus on selected natural areas and present the stakeholders that are directly involved in their management. These different sites are managed by stakeholders with different mission statements:

1. The Tour du Valat (TdV) Nature Reserve is a 2,500 ha area privately acquired in 1947, of which 1,071 ha is a closed nature reserve since 1984 (Mathevet 2004), with public access strictly denied. The TdV Nature Reserve is managed by the TdV Foundation, which follows a nature preservation mission statement within the closed reserve. In addition, it operates extensive livestock farming and organic agriculture in the rest of the area. The TdV Nature Reserve has a research center with about 70 employees from different disciplines related to wetland research as well as managers and rangers, who are partly involved in the management of the site. The research center regularly welcomes scientific events and the researchers carry out some of their experiments in the entire TdV Nature Reserve.

2. The National Reserve of Camargue was created in 1927 in order to conserve the 13,000 ha wetland's natural capital, mainly characterised by the Vaccares Lagoon. It is nowadays managed by a team of 12 people that belong to the National 
Table 3 Interrelation stakeholder linkage matrix (adapted from Chan 1995)

\begin{tabular}{|c|c|c|c|c|c|c|}
\hline \multicolumn{7}{|l|}{ Government } \\
\hline NPA & 个म & & & & & \\
\hline JNF KKL & 个म & 个ฟH & & & & \\
\hline SPNI & & 个म & $\downarrow$ & & & \\
\hline Researchers & & $\uparrow$ & $\uparrow \downarrow$ & & & \\
\hline Agamon & & $\downarrow$ & 个म & H & & \\
\hline \multirow[t]{2}{*}{ Farmers } & $\mathscr{H}$ & & $\downarrow \mathscr{H}$ & ヘฟタ & ヘฟभ & $\downarrow \mathscr{H}$ \\
\hline & Government & NPA & JNF KKL & SPNI & Researchers & Agamon \\
\hline
\end{tabular}

Caption: $\mathscr{H}$ Cooperative action; $\uparrow$ Complementarities; $\downarrow$ Conflict of interest

Society of Nature Protection (a national NGO) (Picon 2008). The managing organisation follows a nature preservation mission statement within the nature reserve, and regularly monitors the ecosystem for either their own management or for scientific purposes by external researchers. The National Reserve includes a visitor path with sheltered observatories for public awareness and a small visitor center at the entrance of the path.

3. The Marais du Vigueirat was created in 1982, to conserve a 1,029 ha wetland, with a team of about 40 people (some with temporary jobs), belonging to the "Amis du Marais du Vigueirat", a local NGO. The Marais du Vigueirat follows a mission statement of nature conservation, integrated in local development. They promote educational activities on-site for raising public awareness and attracting tourists to the area, thus providing jobs for local people that work on-site. Hence they are thus supported by local authorities and inhabitants. The Marais du Viguerat is in the process of becoming a national nature reserve.

4. The Pont de Gau Park is a 60 ha site which acquired its Ornithological Park status in 1974. The park's ecosystem management focuses on public awareness and engagement for wetlands and their avifauna.

The four above natural areas are within the area of the Camargue Regional Natural Park (PNRC), which is a semi-public regional framework for sustainable activities that was created in 1970 (see Fig. 3) The PNRC is a 101,245 ha area managed by a team of 35 wetland experts and managers. It is a coordination structure, whose mission is to promote natural and cultural heritage by implementing their Charter. There are additional natural areas within the PNRC, but we selected the ones above due to their similarities to the sites in the Hula Wetland, in terms of ecosystem management.

In the Camargue Wetland area, 18 stakeholders from the above described organisations were selected and interviewed based on a similar questionnaire as the one used at the Hula. The information collected during the interviews was completed with literature review.

Link between Camargue's management system and the provision of ecosystem services

As in the Hula Wetland, the Camargue has several managing organisations, distributed over the whole wetland area. These organisations promote cultural and habitat services to a different extent depending on the organisation's status and goals. For instance, the TdV is a nature reserve whose priority is to host waterbirds (habitat services). It welcomes monitoring but it is closed to the general public. In contrast, the Marais du Viguerat's priority tasks are raising public awareness and engagement (cultural services). The National Reserve of Camargue is managed under a mixed management regime, since it is partly meant to provide the best conditions for the development of local fauna and flora and another part is partly developed to promote public awareness and engagement (cultural and habitat services). Finally, the Ornithological Park of Pont de Gau promotes tourism, under a highly interventionist management regime, to ensure the presence of emblematic birds (cultural and habitat services). These management types are complementary across the Camargue and allow the provision of cultural and habitat services, while maintaining (semi) natural ecosystems and promoting 
nature tourism. In addition, the state of the ecosystems in the protected areas also depends on water management at the larger, Camargue Wetland scale. The PNRC allows a dialogue between different stakeholders through a water commission (Dervieux et al. 2006). It brings together representatives of various socio-economic activities in the area and it decides on water management in the Camargue. This management involves trade-offs between the often conflicting demands of different stakeholders (e.g. protected areas managers, local authorities, farmers, hunters, fishermen). Even though it is not always possible to meet all the requests and coordinate the management of the whole territory, this opportunity for dialogue enables the stakeholders to understand and update each other on the decisions and changes (Mathevet et al. 2011).

\section{Discussion}

Method used for stakeholders analysis

The stakeholder analysis method used here is particularly relevant for natural resource management issues such as those of the Hula Wetland. The method can identify natural resource problems and different stakeholder interests, in cross-cutting systems (referring to natural systems such as aquifers or watersheds). In addition, it highlights various ES that are used by different stakeholders (points underlined by Grimble et al. 1995; Grimble and Wellard 1997).

There are challenges and limitation to this method (Grimble et al. 1995): (1) It tends to treat different stakeholder groups as distinct entities, whereas in reality such social groupings are often not distinct. In a case-study like the Hula Wetland, where stakeholder analysis is being applied as a tool supporting a practical and participatory effort at conflict resolution between groups, overlaps between groupings proved to be problematic; (2) Given biases in accessible information, making more information available about the interest and decision-making criteria of less powerful groups may play into the hands of more powerful groups. In addition, the information gathered by smaller groups with fewer representatives might also be limited and biased due to the small amount of people available and interviewed; (3) The information collected may be biased due to the nature of the method used (semi-structured interviews).
In addition, it is more difficult to reach consensus over stakeholder categories in semi-structured interviews (Reed et al. 2009). Finally, when using a snowball sampling method to select stakeholders to be interviewed, there may be a selection bias, linked to the social network of the first individuals interviewed (Reed et al. 2009). We expect the selection bias to be low in the Hula Wetland, due to the small number of stakeholders involved in the Hula Wetland management.

Results of comparing the Hula and Camargue management systems

The ES concept helps illuminate the Hula Wetland management in a comprehensive manner, and highlights the need and opportunities for more coordination and complementarity between the different managing bodies. Both Hula and Camargue have similar ecological and environmental characteristics and similar management approaches. However, the Camargue's PNRC has a more holistic vision of all the activities in the wetland and acts as the coordinating body for the different managing organisations in the Camargue and the committees in place. The PNRC allows a platform for the different organisations to discuss and coordinate their management. Unlike the Hula, the managers of the four analysed nature protected areas follow their different mandates and ecosystem management regime and do not try to compete with the other agencies for the provision of similar ES types. They have a more holistic view of the ES provided by the different sub-areas. By using the ES concept in a stakeholder analysis we show that in the Hula Wetland, the different conservation organisations often promote the provision of similar ES instead of working in collaboration and aiming at more complementarity in their work for the conservation and sustainable use of the Hula Wetland.

Brauman et al. (2007) reviewed policy tools that were useful for ES protection and provided several examples where the ES concept was applied to management (see references in p. 87 88). They underlined the fact that new institutional mechanisms to provide for ES delivery are required and that information is needed to help design conservation and management schemes.

To overcome the problems that were highlighted in this paper, we propose a new institutional mechanism at the Hula Wetland, similar to the one in the Camargue 


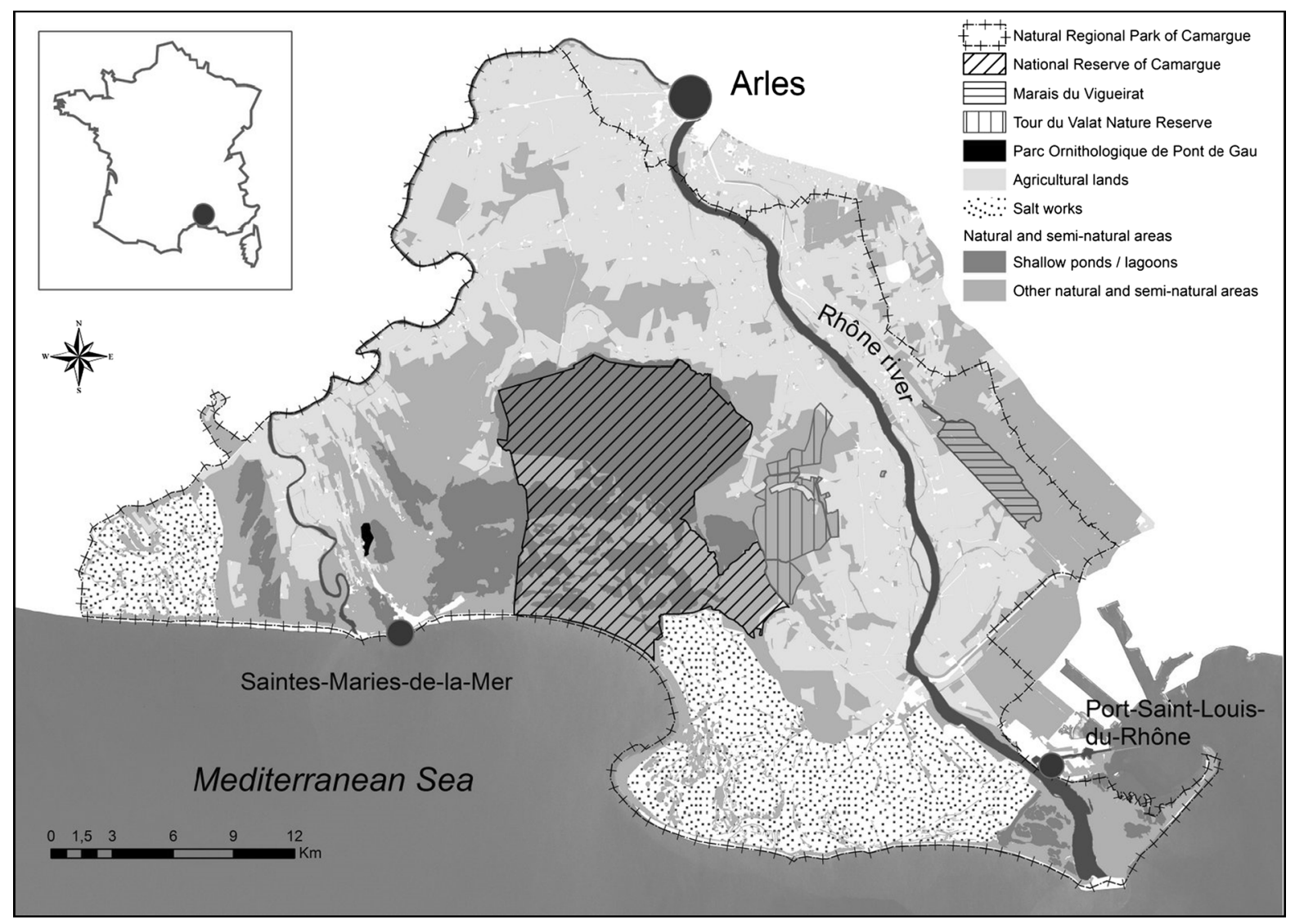

Fig. 3 Map of natural areas in the Camargue Wetland. Data source: PNRC, Pole Evaluation et Prospective, 2011

Wetland. Such a coordinating mechanism should have a broad vision of the management of the whole area and work with defined goals regarding the different important and necessary issues in the wetland: nature conservation, tourism, agriculture and water. It would coordinate all the activities and committees operating currently and allow a better dialogue between different stakeholders, helping them work together and build true cooperation. Regarding the organisations managing different natural areas, such a coordinating mechanism would legitimate their different management regimes and help them coordinate their activity. Since the Hula Wetland area would in that case be seen as an integral entity, the two natural areas will be complimentary, thus keeping the diversity in ES provision. In the report submitted for the nomination of the Hula as a World Heritage Site, a similar coordinating mechanism initiative was proposed (Labinger and Skutelsky 2005). A model for a successful neutral coordinating body in Israel is the non-hierarchical and non-voting administration that was established in 2003 for the coordination of the management and activities in the Jordan Sources Stream Administration (http://www. galil-elion.org.il/).

\section{Conclusion}

Both the Agamon Site and the Hula Nature Reserve complement each other to maintain a healthy balance of ES provided by the Hula Wetland area as a whole. The touristic activities in the Agamon Site are very developed, whereas the Hula Nature Reserve opens only a small part of its area to the public. In order to keep the valuable and unique habitat services which it currently provides, the nature reserve probably needs to stay closed to the public, with no disturbance in its closed areas. The small trail that is open to the public is well defined and limits the number and concentration of visitors to that area. Such open area should not be 
perceived as a problem for the NPA, but as a tool to promote their nature preservation regime, since it allows people to observe and enjoy the large protected areas around it, educating them and raising their awareness for conservation issues. The Hula Nature Reserve has a rich diversity of plant and animal species and due to its uniqueness, is an important asset for the country. In addition to the new coordinating mechanism, we suggest that the state (e.g. Ministry of the Environment) strongly supports the NPA's management regime and encourage them keep the nature reserve visitor-free. To finance this, the nature reserve should implement a mechanism for better distribution of the income from ecotourism and possibly other benefits from the public services provided by the area. Such mechanisms could also be established by the new coordinating mechanism.

In this study, we tested how the use of the ES concept may contribute to improve the conservation of wetland natural areas. The use of the ES concept enabled us to identify stakeholder interests in the Hula Wetland in a systematic and more holistic manner and thereby highlights problems (e.g. poor coordination or conflicts between stakeholders) and opportunities to improve conservation management of the wetland.

Acknowledgments Financial support was gratefully received from the Smaller Winnikow Fellowship Fund for Environmental Research, the Israeli Ministry of Science and Technology, the French Ministry of Foreign and European Affairs, and the French Ministry of National Education, Higher Education and Research. The authors thank Rosi Siber and Maryse Thollon for their help with preparing the GIS maps of the Hula and Camargue, respectively. We also thank Ivana Logar, Idan Barnea and Zev Labinger for their useful comments. We thank all interviewed stakeholders for the invaluable information that they shared with us. Finally, we thank two anonymous reviewers for their valuable comments.

\section{References}

Amir S, Rechtman O (2006) The development of forest policy in Israel in the 20th century: implications for the future. For Policy Econ 8(1):35 51

Armstrong D, Gosling A, Weinman J, Marteau T (1997) The place of inter rater reliability in qualitative research: an empirical study. Sociology 31(3):597 606. doi:10.1177/ 0038038597031003015

Avni T (2003) The effects of institutions on open spaces land scapes and preservation patterns in Israel (In Hebrew). Dissertation, Geography Department, Hebrew University of Jerusalem
Avnimelech Y (1999) The drainage of the Hula Valley (Israel). A case study of a sustainable (or non sustainable) water development project. Water for the future, the West Bank and Gaza Strip, Israel and Jordan. N. R. Council. National Academy Press, Washington

Avnimelch Y, Dasberg S, Harpaz A, Levin I (1978) Prevention of nitrate leakage from the Hula Basin, Israel: a case study in watershed management. Soil Sci 125:233 239

Barnea I (Ed) (2011) The Hula project monitoring system, report of 2009 2010. Migal, Kyriat Shemona. Submitted to the water authority and KKL (in Hebrew)

Barnett HJ, Morse C (1963) Scarcity and growth. The eco nomics of natural resource availability. Resources for the future. The Johns Hopkins Press, Baltimore

Brauman KA, Daily GC, Duarte TK, Mooney HA (2007) The nature and value of ecosystem services: an overview highlighting hydrologic services. Annu Rev Environ Re sour 32:67 98

Cast A, MacDonald DH, Grandgirard A, Kalivas T, Strathearn M, Sanderson M, Bryan B, Frahm D (2008) South Australian Murray Darling basin environmental values report. CSIRO, Water for a Healthy Country National Research Flagship

Chan M (1995) Tree resources in Northern Thailand. local stakeholders and national policy. Natural Resources Insti tute, Chatham

Cohen Shacham E, Dayan T, Feitelson E, de Groot RS (2011) Ecosystem service trade offs in wetland management: drainage and rehabilitation of the Hula, Israel. Hydrol Sci J 56(8): 15821601

Collins Kreiner N, Israeli Y (2010) The Agmon Lake: sup porting an integrated soft approach to ecotourism devel opment. Tourism Geogr 12(1):118 139

Committee on Sustainable Water Supplies for the Middle East (1999) Water for the future: The West Bank and Gaza Strip, Israel, and Jordan. National Academies Press, Washington

Costanza RR, d'Arge R, De Groot R, Farber S, Grasso M, Hannon B, Limburg K, Naeem S, O’Neill RV, Paruelo J, Raskin RG, Sutton P, van der Belt M (1997) The value of the world's ecosystem services and natural capital. Nature 387(6630):253 260

Daily GC, Ellison K (2002) The new economy of nature: the quest to make conservation profitable. Island Press, Washington

De Groot RS, Wilson MA, Boumans RMJ (2002) A typology for the classification, description and valuation of ecosystem function, goods and services. Ecol Econ 41(3):393 408

De Groot RS, Alkemade R, Braat L, Hein L, Willemen L (2010) Challenges in integrating the concept of ecosystem ser vices and values in landscape planning, management and decision making. Ecol Complex 7(3):260 272

Dervieux A, Jolly G, Allouche A (2006) Gestion de l'eau et projet de territoire: vers une gestion intégrée du delta du Rhône. VertigO 7(3)

Dimentman C, Bromley HJ, Por FD (1992) Lake Hula. Recon struction of the fauna and hydrobiology of a lost lake. Israel Academy of Science and Humanities, Jerusalem

Duany M (2010) From drainage to conservation of the Hula wetland: tracing the dynamics of nature intervention (in Hebrew). Dissertation, University of Haifa, Israel 
Feitelson E, Rosenthal G (2012) Desalination, space and power: the ramifications of Israel's changing water geography. Geoforum 42(2):272 284

Feitelson E, Fischhendler I, Kay P (2007) Role of a central administrator in managing water resources: the case of the Israeli water commissioner. Water Resour Res 43(11):1 11

Furth DG (1976) The huleh and its lost aquatic leaf beetle. Atala 4(1 2$): 49$

Gophen M, Tsipris Y, Meron M, Bar Ilan I (2003) The man agement of Lake Agmon wetlands (Hula Valley, Israel). Hydrobiologia 506 509(1 3):803 809

Grimble RJ (1998) Stakeholder methodologies in natural resource management. Natural Resources Institute. Avail able: http://www.dfid.gov.uk/Pubs/files/BPG02.pdf

Grimble RJ, Wellard K (1997) Stakeholder methodologies in natural resource management: a review of principles, contexts, experiences and opportunities. Agr Syst 55:2

Grimble RJ, Chan M, Aglionby J, Quan J (1995) Trees and trade offs: a stakeholder approach to natural resource management. Gatekeeper Series no. 52. IIED, London

Gutman M, Kaplan D, Gutman R (2001) Restoration and con servation of fauna and flora in the re flooded hula wetland in Northern Israel. Final report, 1997 2001, LIFE Third Countries. TCY/97/IL/038

Hambright KD, Zohary T (1998) Lakes Hula and Agmon: destruction and creation of wetland ecosystems in northern Israel. Wetl Ecol Manag 6(2 3):83 89

Jordan Sources Stream Administration (2009) Life project for the Jordan River Master plan (in Hebrew)

Klein M (1998) Water balance of the upper Jordan river basin. Water Int 23(4):244 248

Kremen C (2005) Managing ecosystem services: what do we need to know about their ecology? Ecol Lett 8(5):468 479

Labinger Z, Skutelsky O (2005) Great rift valley migration flyway. The hula. Nomination for inscription on the world heritage list. Keren Kayemet LeIsrael

Leopold A (1949) A sand county almanac, and sketches here and there. Oxford University Press, London, p 226

MA (Millennium Ecosystem Assessment) (2005) Ecosystems and human well being: multiscale assessments. findings of the sub global assessments working group of the millen nium ecosystem assessment. Island Press, World Resour ces Institute, Washington

Markel D (2004) The Hula Project, the Israeli wetland project. Agamit 166:6 10 (in Hebrew)

Markel D, Sass E, Lazar B, Bein A (1998) Biogeochemical evolution of a sulfur iron rich aquatic system in a reflooded wetland environment (Lake Agmon, northern Israel). Wetl Ecol Manag 6:103 120

Mathevet R (2004) Camargue incertaine. Sciences, usages et natures. Buchet Chastel, Ecologie, France

Mathevet R, Etienne M, Lynam T, Calvet C (2011) Water man agement in the Camargue biosphere reserve: insights from comparative mental models analysis. Ecol Soc 16(1):43

Maynard S, James D, Davidson A (2010) The development of an ecosystem services framework for South East Queensland. Environ Manag 45(5):881 895

Nash RF (1989) The rights of nature: a history of environmental ethics. The University of Wisconsin Press, Madison, Wis consin 290
Olsvig Whittaker L, Oron T, Kaplan D, Hassan G (2005) Conservation of Mediterranean wetlands: Israel's two "Ramsar" sites, En Afeq and Hula nature reserves. Isr J Plant Sci 53:253 259

Patton MQ (1990) Qualitative evaluation and research methods. SAGE Publications, Thousand Oaks

Paz U (1975) Rehabilitation of the Hula Nature Reserve (Hebrew). Nat Conserv Isr 1:116 206

Picon B (2008) L'espace et le temps en Camargue. Actes Sud, Arles, France

Ramsar Convention Secretariat (2010) Wise use of wetlands: concepts and approaches for the wise use of wetlands. Ramsar handbooks for the wise use of wetlands, vol 1, 4th edn. Ramsar Convention Secretariat, Gland, Switzerland

Ramsar COP9 (2005) Resolution IX.9: the role of the Ramsar convention in the prevention and mitigation of impacts associated with natural phenomena, including those induced or exacerbated by human activities. Available: http://www.ramsar.org/pdf/res/key res ix 09 e.pdf

Ramsar COP10 (2008) Resolution X.19: "Wetlands and river basin management: consolidated scientific and technical guidance. Available: http://www.ramsar.org/pdf/res/key res x 19 e.pdf

Reed MS, Graves A, Dandy N, Posthumus H, Hubacek K, Morris J, Prell C, Quinn CH, Stringer LC (2009) Who's in and why? A typology of stakeholder analysis methods for natural resource management. J Environ Manage 90(5):1933 1949

Scolozzi R, Morri E, Santolini R (2012) Delphi based change assessment in ecosystem service values to support strategic spatial planning in Italian landscapes. Ecol Indic 21:134 144

Seppelt R, Dormann CF, Eppink FV, Lautenbach S, Schmidt S (2011) A quantitative review of ecosystem service studies: approaches, shortcomings and the road ahead. J Appl Ecol 48(3):630 636

Shaham G, Minzker H, Kenaan G (1990) Alternative utilization of the Hula lands a feasibility study. Israel Ministry of Agriculture, Hula Committee (in Hebrew)

Shmueli M, Izhaki I, Zinder O, Arad Z (2000) The physiological state of captive and migrating Great White Pelicans (Pelecanus onocrotalus) revealed by their blood chemistry. Comp Biochem Physiol Part A Mol Integr Physiol 125(1):25 32

Shy E, Beckerman S, Oron T, Frankenberg E (1998) Repopu lation and colonization by birds in the Agmon wetland, Israel. Wetl Ecol Manag 6:159 167

Skutelsky O, Oron T (2008) Hula's management plan (in Hebrew), Nature and Parks Authority

Tal A (2006) Seeking sustainability: Israel's evolving water management strategy. Science 313(5790):1081 1084

TEEB (2010) The economics of ecosystems and biodiversity: ecological and economic foundations. In: Pushpam Kumar (ed) Earthscan, London, Washington

Thompson P (2000) Re using qualitative research data: a per sonal account. Forum: qualitative social research, North America. Available: <http://www.qualitativeresearch.net/ index.php/fqs/article/view/1044>. Accessed 18 Mar 2013

Trop T (2001) Nature conservation policy in Israel: formation process, trends and future directions (In Hebrew). Disser tation, The Technion Israel Institute of Technology 